\title{
İndüklenmiş Pluripotent Kök Hücrelerin Elde Edilmesi ve Rejeneratif Tıpta Uygulanabilirliği
}

\author{
Nevra Pelin CESUR, Nelisa TÜRKOĞLU LAÇIN
}

Yıldız Teknik Üniversitesi Fen-Edebiyat Fakültesi, Moleküler Biyoloji ve Genetik Anabilim Dalı, İstanbul.

\section{ÖZET}

2006 yılında Takahashi ve Yamanaka dört transkripsiyon faktörünün (Oct4, Sox2, Klf4 ve c-Myc) fibroblast hücrelerine aktarılması ve bu transkripsiyon faktörlerinin ifadesinin pluripotent kök hücre elde etmek için yeterli olduğunu bildirmis ve somatik hücrelerin geriye programlanarak elde edilen bu hücreler indüklenmiş pluripotent kök hücreler (IPKH) olarak adlandırılmıştır. Daha sonraki yıllarda transkripsiyon faktörleri ve yeniden programlama şartlarının optimizasyonu ile ilgili birçok çalışma yapılmıştır. Bugüne kadar farklı somatik hücrelere transkripsiyon faktörlerinin farklı metotları ile tanıtımı ya da transkripsiyon faktörlerinin farklı kombinasyonlarının kullanımının etkisi araştırma konusu olmuştur. Somatik hücrelerin yeniden programlanması amacı ile birçok farklı vektör sistemi bulunmaktadır. Bu vektör çeşitlerinin İPKH eldesi için verimlilikleri birbirlerinden farklılık göstermektedir. Bu derlemede, kök hücrelerin genel özellikleri ve uygulama alanlarının irdelenmesinin yanı sıra ağılıklı olarak indüklenmiş pluripotent kök hücrelerinin elde edilmesi üzerinde durulmuştur. Ayrıca İPKH'lerin klinik amaçlı kullanım potansiyellerine de değinilmektedir.

Anahtar Kelimeler: Kök hücreler. Kök hücre çeşitleri. Rejeneratif tıp. İndüklenmiş pluripotent kök hücreler. İndüklenmiş kök hücre eldesi.

Generation of Induced Pluripotent Stem Cells and Applications in Regenerative Medicine

\section{ABSTRACT}

In 2006, Takahashi and Yamanaka reported that the transfer and expression of four transcription factors (Oct4, Sox2, Klf4, and c-Myc) into fibroblast cells were sufficient to obtain cells similar to embryonic stem cells. The cells obtained by reprogramming of somatic cells are called induced pluripotent stem cells (IPSC). In the following years, various studies were carried out for the optimization of transcription factors and reprogramming conditions. Until now, the introduction of transcription factors to different somatic cells or stem cells by various methods or the effect of using different combinations of transcription factors has been the subject of research. There are many different vector systems to reprogramme somatic cells. The efficiencies of the vector types for obtaining IPSC differ from each other. In this review, the general properties of stem cells and their application areas are discussed, as well as the acquisition of induced pluripotent stem cells and their potential for clinical use.

Key Words: Stem cells. Stem cell types. Induced pluripotent stem cells. Regenerative medicine. Generation of induced pluripotent stem cell.

Geliş Tarihi: 28.Eylül.2020

Kabul Tarihi: 18.Ocak.2021

Dr. Nelisa TÜRKOĞLU LAÇiN

Yıldız Teknik Üniversitesi,

Fen-Edebiyat Fakültesi,

Moleküler Biyoloji ve Genetik Anabilim Dalı,

İstanbul.

Tel: 05322257368

E-posta: nelisalacin@gmail.com

Yazarların ORCID ID Bilgisi:

Nelisa TÜRKOĞLU LAÇiN: 0000-0003-3176-0902

Nevra Pelin CESUR: 0000-0003-3979-6053
İnsanoğlu tarih boyunca yaşlanma karşıtı tedavileri geliştirmek, hastalıkların üstesinden gelebilmek, insan ömrünü uzatabilmek için büyük çabalar sarf etmiştir. Günümüzde bu amaç doğrultusu da genetik mühendisliği, doku mühendisliği ve moleküler biyoloji tekniklerinden yararlanılmaktadır. Son yıllarda oldukça popüler olan kök hücrelerin kullanımı ile tedavi yöntemleri önemli bir yer kazanmıştır ${ }^{1,2}$. Bunlara ek olarak, bilim adamları laboratuvarda kök hücreleri; yeni ilaçları taramak, gelişimsel büyümeyi incelemek, doğum kusurlarının nedenlerini belirlemek ve model sistemler geliştirmek için kullanmaktadırlar. Diğer bir yandan kök hücre çalışmalarının kullanımı sayesinde insan vücudunun birçok yenilenme ve onarım mekanizması çözümlenmiş ve aynı zaman da temel toksikoloji ve hatta kanser çalışmaları için in vitro insan hastalık modellerinin oluşturulabileceği gösterilmiştir ${ }^{3,4}$. Dahası bu tür çalışmalar organ nakli ve terapötik 
amaçlı gen terapisi gibi tedavi yaklaşımlarına yeni pencerelerin açılmasına olanak sağlamıştır ${ }^{5}$. Ayrıca Parkinson hastalığı, omurilik yaralanması ya da işitme kaybı gibi tedavi edilmesi zor hastalıklar için kök hücrelerin kullanımı önemli çalışma alanlarıdır ${ }^{6,7}$.

Kök hücreler, erken embriyonik dönem ve büyüme sırasında vücutta birçok farklı hücre tipine gelişme potansiyeli olan özel hücrelerdir. Tüm kök hücrelerin üç temel özelliğinden bahsedebiliriz: Uzun süreli bölünebilme yeteneği, özelleşmemiş hücreler olması ve özelleşmiş hücre tiplerine dönüşebilmeleridir ${ }^{8}$. Ayrıca birçok dokuda ve yüksek organizasyonlu canlılarda organların fonksiyonel özelliklerinin devamlılığı için önemli role sahiplerdir ${ }^{9}$. Bunlara ek olarak kök hücreler farklılaşma potansiyellerine göre sınıflandırılabilirler. Bunlardan ilki olan totipotent kök hücreler vücut içindeki tüm hücre tiplerini oluşturabilen kök hücrelerdir ${ }^{10}$. Oosit ve spermin döllenip zigot oluşturduktan sonra gelişimin dördüncü gününe kadar olan hücrelerin her biri için bu tür hücre farklılaşma potansiyelinden bahsedilebilir. İnsan embriyosunda, sadece 8 hücreli evreye kadar döllenmiş embriyolar totipotent hücreler olarak kabul edilir ${ }^{11,12}$. Totipotent kök hücreler plasenta ve embriyoyu oluşturma kabiliyetine sahip olan hücrelerdir. Pluripotent kök hücreler tek başlarına bir organizmayı oluşturamazlar ve plasentayı oluşturma kabiliyetine de sahip değillerdir. Ancak vücutta 200 farklı hücre tipine farklanma potansiyeline sahiptirler $^{10}$. Bu farklılaşma mezodermal, ektodermal ve endodermal kökenli olmak üzere vücuttaki neredeyse tüm özelleşmiş hücre tiplerini kapsamaktadır. Ancak trofoblast oluşturamazlar. Ayrıca ön implantasyonun blastosist aşamasındaki iç hücre kitlesinden türetilen embroyonik kök hücreler in vitro koşullarda çoğaltılabilir ve elde edilen bu hücreler pluripotent özelliğini koruyabilmektedir $^{12}$. Multipotent kök hücreler ise yalnızca sınırlı hücre tipine farklılaşabilirler. Örneğin hematopoetik kök hücreler lenfosit ve miyeloid seri hücrelerini oluşturabilirler. Daha sonra bu hücre serileri de makrofajlara, lenfositlere, eritrositlere ve mast hücrelerine özelleşebilmektedirler ${ }^{13}$. Diğer bir kök hücre tipi ise tek bir hücre tipine dönüşebilen öncül hücreler olarak da adlandırılan unipotent kök hücreleridir. Spermatogonial kök hücreler bu grup için verilebilecek en yaygın ve bilinen örnektir ${ }^{10}$. Kök hücreler asimetrik bölünme ile bölündüğün de oluşan yeni hücrelerden birisi kök hücre yeteneğini oluşturma ve diğeri özel bir işlevi olan başka bir hücre tipine özelleşecek olan progenitor hücreyi oluşturmaktadır ${ }^{14}$. Çünkü kök hücreler simetrik bölünmenin yanın da genellikle simetrik olmayan bölünme sergilemektedir. $\mathrm{Bu}$ iki bölünme çeşidinin dengeli olması canlıdaki homeostaz için önemlidir ${ }^{15}$. Son yıllarda yapılan çalışmalar ile canlıda rejenerasyonun fazla olduğu deri ve bağırsak epiteli gibi birçok dokudan kök hücreler elde edilmiştir. Bunlara ek olarak insan yağ dokusundan izole edilen kök hücreler için araştırmalar devam etmektedir ve bu dokuların diğer kök hücre kaynaklarına kıyasla daha fazla kök hücre bulundurduğu bilim insanları tarafından keşfedilmiştir ${ }^{16}$.
Bilim insanlarının bu zamana kadar yaptığı çalışmalarda genellikle fare ve insan hücrelerinden alınan kök hücreler üzerinde araştırmalar yürütülmektedir ve kök hücreleri farklanma potansiyellerinden farklı özelliklerine göre de sinıflandırmaktadırlar. Embriyonik veya embriyonik olmayan ya da somatik veya olgun hücreler olarak sınıflandırılmaktadır ${ }^{17}$. Embriyonik olmayan kök hücreler; hematopoetik kök hücreler, stromal (mezenkimal) kök hücreler ve organlarda yerleşik diğer erişkin kök hücreler olmak üzere üç ana başlık altında incelenebilir ${ }^{12}$. Özellikle Yamanaka ve ark. bazı özel yetişkin hücrelerin kök hücre benzeri bir durum alabilmeleri için genetik olarak "yeniden programlanmasına" izin verecek koşulları belirleyerek yeni bir dönüm noktası başlattılar. Bu yeni kök hücre tipi indüklenmiş pluripotent kök hücreler olarak adlandırılmıştır ${ }^{18}$. Bu hücreler kendini yenileyebilme ve vücudun hemen hemen tüm hücrelerine özelleşebilme yeteneğine sahiptir.

\section{Embriyonik Kök Hücreler}

Embriyonik kök hücreler özellikle uterus duvarına implantasyon öncesi gelişim aşamasında blastosistin iç hücre kütlesinden izole edilen pluripotent yapılı kök hücrelerdir ${ }^{19}$. Elde edilen embriyonik kök hücrelerin in-vitro ortamdaki kolonizasyonu şekil 1'de ana hatlarıyla gösterilmiştir;

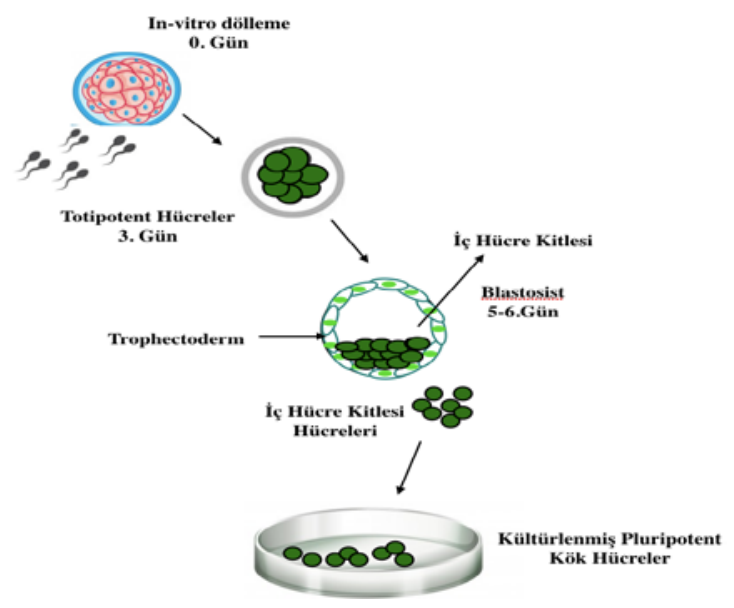

Şekil 1.

Embriyonik gelişimde totipotent ve pluripotent kök hücre kolonizasyonu

İnsanlarda ilk farklanma olayı, embriyonik gelișimim yaklaşık beş günlük evresinde bir dış hücre katmanının ileride plasentayı oluşturmak üzere iç hücre kütlesinden (İHK) ayrılması ile meydana gelir ${ }^{19}$. Eğer İHK normal embriyonik mikro-çevresinden çıkarılırsa ve uygun koşullar altında kültüre edilirse İHK'den türetilen hücreler süresiz olarak çoğalmaya devam edebilirler ve aynı zamanda vücudun herhangi bir hücre tipini oluşturmak için gerekli gelişim potansiyelini devam ettirebilirler. Bu hücrelerin mükemmel bir pluripotent kapasiteye sahip oldukları söylenebilmektedir ${ }^{20,21}$. Şekil 2'de İHK'deki embriyonik kök hücre kolonileri gösterilmiştir. 


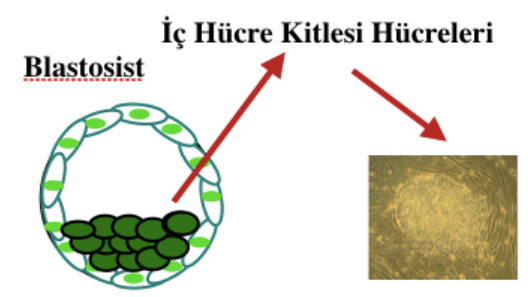

Embriyonik Kök Hücre Kolonisi

Şekil 2.

Blastosist evresinde embriyonik kök hücreler

Özellikle insan embriyonik kök hücre elde edilmesi amacı ile döllenmenin bir kültür kabında (petri) gerçekleşmesinin sağlanması için oositlerin ve spermlerin bir araya getirildiği bir işlem olan in vitro fertilizasyon da (IVF) incelenebilmektedir ${ }^{22}$. Aslında, teorik olarak bu hücrelerin birçok alanda kullanımı şekil 3’te özetlendiği şekilde mümkündür.

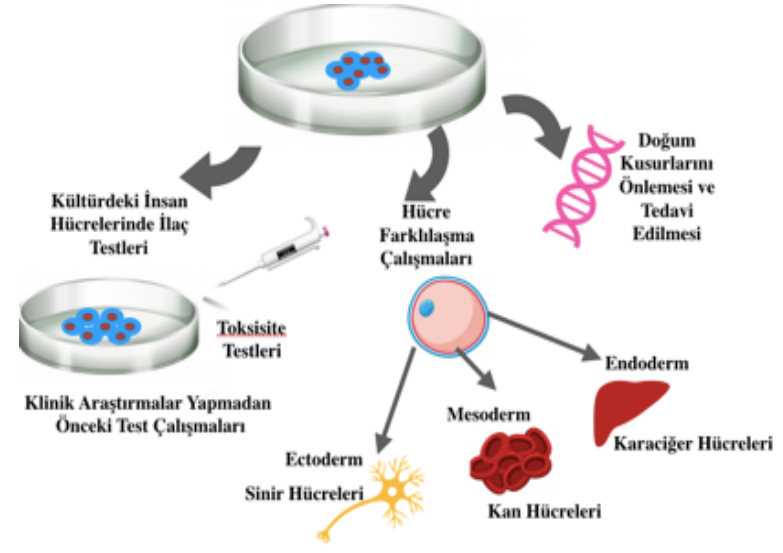

Şekil 3.

Elde edilen kök hücrelerin kullanım alanları

Embriyonik kök hücrelerin kültürü için orijinal protokol de kültür kabının iç yüzeyi fare embriyonik fibroblast (FEF) hücreleri ile kaplanmaktadı2 ${ }^{23}$. Bu tabaka besleyici katman olarak adlandırılır ve şekil 4 'te genel hatlarıyla gösterilmektedir.

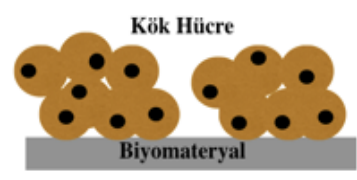

Ortak kültürleme

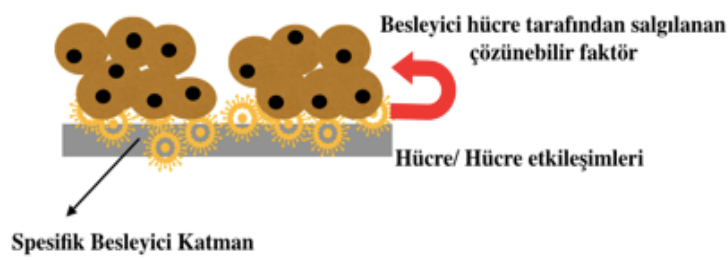

Şekil 4.

Elde edilen kök hücreler için uygun mikro çevrenin sağlanması
Bu katman, hücreler için uygun mikro çevrenin sağlanmasına yardımcı olmaktadır. Besleyici tabaka kök hücreler için gerekli olan bazı önemli molekülleri hücrelere tedarik eder ancak fare hücrelerindeki virüslerin veya diğer yabancı makro moleküllerin de insan hücrelerine bulaşması riski bu ortamda kültürü yapılan kök hücrelerin klinik amaçla kullanımını kısıtlanmak$\operatorname{tad}^{20}{ }^{20}$. Bir embriyonik kök hücre hattını kültüre etme işlemi çok verimli bir işlem değildir. Bu nedenle her bir ön implantasyon aşamasındaki embriyodan hücreler bir kültür kabına yerleştirildiğinde hatlar üretilemez. Ancak eğer hücreler yeterli sayıya ulaşmış ve sağlıklı ise petriyi kaplayacak kadar bölünmüş ve çoğalmışsa hücreler dikkatlice pasajlanarak yeni ve taze kültür kaplarına ekilir. Hücrelerin yeniden kaplanması veya alt kültürlenmesi işlemi birçok kez ve aylarca tekrarlanır. Hücreleri alt kültürlemenin her bir döngüsü pasaj olarak adlandırılır. Hücre kültüründe farklılaşmadan altı veya daha fazla ay boyunca çoğalan bu kök hücreler pluripotent özellik gösterir ve embriyonik kök hücre hattı olarak adlandırılır. İşlemin herhangi bir aşamasında hücreler dondurulabilir ${ }^{12}$. İstenilen embriyonik kök hücreler elde edildikten sonra birçok farklı özelleşmiş hücreye farklanmaları için manipüle edilebilir. Ayrıca kültürleme sırasında bazı dış faktörlerin kullanılması hücrelerin daha kolay çoğaltılmasını sağlayabilir. Lösemi İnhibitör Faktörü (LIF) bu faktörlerden en önemlilerindendir ve interlökin (IL)-6 tipi sitokin ailesine aittir. Özellikle fare kök hücreleri çalışmalarında kullanılmaktadır ${ }^{24}$. Bu dış faktör STAT3 proteininin aktivasyonuna neden olmasına rağmen fare kök hücrelerinin nöral hücrelere farklılaşmasını önlemek için yetersizdir. Bu yüzden de kemik morfogenetik proteinlerinin (BMP) ve LIF kombinasyonunun embriyonik kök hücrelerin kendini yenilemesini desteklemek için gerekli olduğu bildirilmiştir $^{25}$. Bu çalışmalar sırasında bilim insanları insan embriyonik kök hücreleri için büyüme faktörlerini de incelemeye başlamıştır. bFGF (özellikle FGF-2) çoğunlukla fibroblast varlığında insan embriyonik kök hücrelerinin çoğalması ve insan kök hücrelerinin klonal büyümesinin sağlanması için kullanılmaktadır. İn vitro kültür ortamında insan embriyonik kök hücreleri gibi kök hücreler FGF2 ve aktivitin desteğine ihtiyaç duyarlar. Bu sayede teratom oluşumu ve pluripotent özellik gösterirler ${ }^{10}$. FGF ailesinde yer alan ligandlar tirozin kinaz aktivitesine sahip dört farklı reseptör üzerinde etkilerini göstererek MAPK, ERK1/2, PI3K/Akt gibi hücre içi sinyal moleküllerinin aktivitesini sağlar. Pluripotent kabiliyetin devamlılığı FGF reseptörleri ile ligandlarının ifadesi ile gösterilmiştir. Bunun yanında aktivinA'nın da insan embroyonik kök hücrelerinde FGF-2 ekspresyonunun indüklediği gösterilmiştir ${ }^{26}$. Bu tip in vitro koşullarda kök hücre kültürü sırasında embriyonik kök hücreler pluripotent ve özelleşmemiş hücre özelliklerinin göstergeleri olan CD9, CD24, Oct-4, alkalin fosfataz, LIN28, Thy-1, SSEA-3 ve SSEA-4'ü ifade eder ${ }^{27}$. 


\section{Yetişkin Kök Hücreler}

Bir doku veya organdaki özelleşmiş hücreler arasında bulunan özelleşmemiş olan hücreler yetişkin kök hücreler olarak adlandırılmaktadır. Aynı zamanda somatik kök hücre olarak da adlandırılırlar. Başlıca rolleri bulundukları dokuyu korumak ve onarmaktır. Yetişkin kök hücrelerin en iyi örneği kan hücrelerini oluşturan kemik iliği hücreleri olan hematopoietik kök hücrelerdir $^{2}$. Özellikle yetişkin kök hücrelerin farklılaşması laboratuvarda kontrol edilebilirse bu hücreler transplantasyon tedavilerinin en önemli oyuncularından biri haline gelecektir. Günümüzde bazı bilim adamları yetişkin kök hücrelerin sadece kemik iliğinde değil aynı zamanda beyinde ve hatta kalp gibi komplike organlarda da bulabileceğini göstermektedir. Aslında bu hücrelerin varlığı ile beyinde üç özelleşmiş beyin hücresinden astrositler, oligodendrositler ve nöronları üreten kök hücrelere sahip olabilir düşüncesini ortaya çıkarmıştır $^{28}$. Bu nedenle bu hücrelerin yerini ve nasıl tespit edilebileceği ile ilgili çalışmalar büyük bir merak konusu haline gelmiştir. Bunun için iki ana yöntem belirlenmiştir. İlk olarak canlı bir dokudaki hücreleri bazı moleküler belirleyiciler ile etiketlemek. İkincisi ise hücreleri canlı bir organizmadan çıkarıp akabinde hücre kültüründe etiketleyerek hücrelerin tekrar birlikte çoğalıp çoğalmadığını tespit etmek için onları başka bir canlıya nakletmektir. Öte yandan yetişkin kök hücrelerin farklılaşma kapasitesini açıklamak için kullanılan terimler vardır. Transdiferansiyasyon buna en güzel örnektir. Terim bazı yetişkin kök hücre tiplerinin hücrelerin öngörülen soyundan beklenen dokular dışındaki organlarda veya dokularda görülen farkl hücre tiplerine farklılaşabileceği anlamını taşır. Örnek olarak kalp kası hücrelerinin kanı oluşturabilecek hücrelere farklılaşması verilebilir ${ }^{29}$.

\section{Indüklenmiş Pluripotent Kök Hücreler}

İndüklenmiş pluripotent hücreler (İPKH), somatik hücrelerden özellikle farelerde karaciğer, pankreas hücresi ve nöral progenitör hücrelerden insanda ise dermal fibroblast, periferik kan hücreleri, keratinosit, üriner epitel hücresi, karaciğer, mide epitel hücreleri, mezenkimal hücreler, $\mathrm{B}$ ve $\mathrm{T}$ hücreleri, nöral kök hücreleri, pankreas hücreleri, progenitör kan hücreleri, kordon kanı hücrelerinin genetik olarak yeniden programlanması ile elde edilmiştir ${ }^{30}$. IPKH eldesinde amaç; hastalıkların tedavisinde, yeni ilaçların testinde, doku mühendisliğini çalışmalarında ve kişiselleştirilmiş tedavilerde kullanılmak için pluripotent kapasite de hücreleri elde etmektir. Özellikle embriyonik kök hücrelere alternatif olması, blastosistlerin bazı işlemlere maruz kalmasını ve insan uterusuna ihtiyacı ortadan kaldırmaktadır. Bu yöntemler hemen hemen tüm ülkelerde etik sorunlar doğurmaktadır. Bizim ülkemizde de 2006 yılında Sağlık Bakanlığı tarafından embriyonik kök hücre çalışmaları durdurulmuştur. Bu nedenle bilim adamları yeni çözümler aramaya başlamışlardır ${ }^{31}$. IPKH'lerin elde edilebilmesi ve çalışılması bu anlamda büyük bir çığır açmıştır. Pluripotent kök hücre eldesi için öncelikle fare hücreleri ile 2006'da akabinde 2007'de insan somatik hücreleri bilim adamları tarafından çalışılmıştır ${ }^{18}$. Fare indüklenmiş pluripotent hücrelerindeki çalışmalar, aynı zaman da pluripotent kök hücrelerin önemli özelliklerini açığa çıkarmıştır. Bu kök hücreler kök hücre belirteçlerini içermekte, üç germ katmanında tümör oluşumu göstermekte, fare embriyosuna enjekte edildiğinde birçok farklı dokuyu oluşturabilme ve ayrıca insan indüklenmiş kök hücrelerinin karakteristik özelliklerini göstermektedirler.

\section{Indüklenmiş Pluripotent Kök Hücre Eldesi}

Yeniden programlama; özelleşmiş bir hücrenin çekirdeğinde sabit bir değişiklik meydana getirmeyi içeren ve daha sonra hücre mitoz yoluyla bölündükçe pluripotent kapasitesini muhafaza edip çoğaltılabilmesine imkan veren önemli bir tekniktir. Bu çekirdek değişiklikleri hücreler için pluripotent yeteneğinin yeniden kazanılmasını sağlayan ve indüklenmiş kök hücrelerinin oluşturulmasında önemli bir tekniktir. Bunun yanı sıra temel olarak üç yöntemle yeniden programlanmış hücre elde edilmektedir ${ }^{29}$.

-Somatik hücre nükleer transferi (SCNT),

-Değiştirilmiş nükleer transfer (ANT),

-Somatik hücreleri ek hücrelerle kaynatma yöntemi.

Şekil-5’te bu temel yaklaşımlar özetlenmektedir.

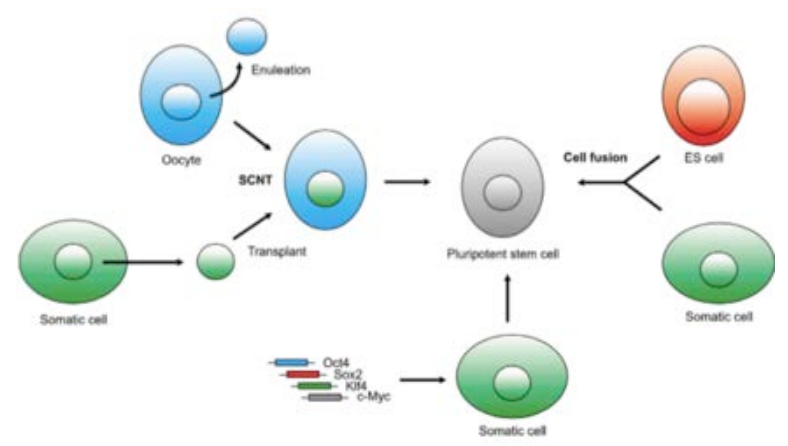

SSekil 5.

IPKH elde edilmesinde farklı yaklaşımlar ${ }^{10}$

\section{Somatik Hücre Nükleer Transfer Yöntemi}

Nükleer transfer yöntemi diploit çekirdeğin transferini belirtir veya somatik hücrenin enükle oositli bir oosit olduğunu söyleyebiliriz ${ }^{32}$. Elde edilen hücreye embriyolara büyüme kabiliyeti gösterebilen yeniden yap1landırılmış hücre denir ${ }^{33}$. Bu transfer elektriksel bir tepki tarafından indüklenen serbest kalsiyum konsantrasyonu veya hücreler arası alanda kimyasal uyarıcı tarafından yapılan bir tür uyarıdır ${ }^{10}$. Elde edilen embriyoların ön implantasyon aşaması uygun bir kültür ortamında devam etmektedir ve geliştirilen embriyolar transfer edilebilmektedir. Bu yöntem ilk kurbağalarda denenmiştir $^{34}$. Hem terapötik hem de üreme amaçlı 
kullanılacak klon üretimi için özellikle önemlidir ${ }^{35}$. Terapötik klonlama, rejeneratif tıpta nükleer transferin potansiyel kullanımı anlamına gelir ${ }^{36}$. Bu prosedürü gerçekleştirmenin amacı klonlanmış bir embriyodan pluripotent hücreler elde etmektir. Bu hücreler genetik olarak donör organizma ile eştir. Bu nedenle terapilerde, hastalık ya da ilaç araştırmalarında uygulanabilen hastaya özgü pluripotent hücreler yaratma kabiliyeti sağlarlar.

\section{Hücre Füzyonuna Bağlı Yeniden Programlama}

Somatik hücreler; embriyonik kök hücreler, embriyonik germ ve embriyonal karsinoma gibi pluripotent kök hücreler ile birleştikten sonra bir pluripotent durumu elde edebilmektedir. İlginçtir ki Tada ve arkadaşları somatik hücrelerin etiketli genlerinin metilasyon modelinin embriyonik hücreler ile füzyonundan sonra değişmediğini ancak embriyonik germ hücreleri ile füzyonundan sonra değiştiğini bildirmiştir ${ }^{37}$. Bu sonuçlar, embriyonik germ hücrelerinin ayrıca metilasyon değişikliği ve hücreler üzerinde asetilasyon etkinliğini içerdiğini göstermektedir. Bunlara ek olarak hibrit hücreler, bazı pluripotent özellikler göstermektedir, bunlar; dokuya özgü genlerin inaktivasyonu, pluripotent özellik ile ilişkili genlerin yeniden aktivasyonu, üçlü germ tabakasında farklılaşma yeteneği, belirli bir epigenetik profil metilasyon kalıplarıdır ${ }^{10}$.

Son zamanlarda Butan ve arkadaşları DNA metilasyon aktivitesinde rol alan hücre füzyonunda aktivasyon ile indüklenen sitidin deaminaz'ın (AID) yeniden programlama teknolojisinde kullanıldığını varsaydılar ${ }^{18}$. İnsan fibroblastlarının OCT4 ve NANOG promotör bölgesinin fare embriyonik kök hücrelerinin füzyonundan sonra replikasyon ve hücre bölünmesi olmadan demetilasyon gösterdiğini, AID'nin aktif bir DNA demetilaz olarak işlev görebileceğini gösterdiler. Ancak AID rolünün tam anlamıyla açıklanamadığı söylenebilir $^{38}$. Daha önce de belirtildiği gibi füzyon hibritleri pluripotent özellikler gösterir ancak hücreler pluripotent füzyon partner hücreleri ile aynı değildir. Füzyon kaynaklı yeniden programlamanın çok etkili olmasına rağmen (yaklaşık \%95) sonuçta ortaya çıkan hibrit hücreler tetraploidideleri ve pluripotent füzyon ortağı hücrelerinden harici genlerin varlığından dolayı terapötik potansiyel için uygun gözükmemektedir. Bilim adamları bu eksiklik modellerinin çoğunlukla oluşturulmuş dış genlerden kaynaklandığını varsaymaktadir ${ }^{10}$.

\section{Transkripsiyon Faktörü Transdüksiyonu}

Günümüzde transdüksiyon yöntemi bilim adamları tarafından önerilen indüklenmiş pluripotent hücreleri elde etmek amacı ile kullanılan en popüler yöntemdir. Bu transdüksiyon modelleri somatik hücrelere embriyonik hücrelerdeki özellikle pluripotensiden sorumlu transkripsiyon faktörlerinin tanıtılması ile uyarılmış pluripotent hücrelerin oluşturulmasını kapsar. Bu transkripsiyon faktörleri 2006'da Takahashi ve Yamanaka tarafından çalışılmıştır. İlk olarak 24 gen tanıtılmıştır. Ancak birkaç yıl sonra, dördünün (Oct-4, Sox2 , Klf ve c-Myc) esas olarak indüklenmiş pluripotent hücrelerinin oluşumu için yeterli olduğunu ileri sürülmüştür $^{39,40}$. Oct3/4 veya diğer bir ismiyle Pou5f1 döllenmiş yumurtada ilk olarak belirlenen gendir ${ }^{41,42,43}$. Blastosistlerin oluşumu için çok önemlidir. Ayrıca bu transkripsiyon faktörünün eksprese edilen oranı hücrenin kaderinde önemli rol oynamaktadır. Oct3/4 ekspresyon oranına göre hücre ya pluripotent seviyede kalır ya da ilkel endoderm ve mezodermin oluşumu ile farklılaşmaya başlar ${ }^{44}$. Oct3/4'ün yanı sıra indüklenmiş pluripotent hücrelerin tespiti için çok önemli olan diğer bir protein DNA'nın küçük oluklarına bağlanan Sox2'dir. Embriyonik kök hücrelerin kendini yenilemesi için gereklidir ${ }^{45,46}$. Erken embriyonik dönemde germ hücreleri ve epiblastlarda eksprese edilir. Özellikle uv, radyasyon, çeşitli kimyasal ve hatta diş faktörler gibi istenmeyen bir faktör tarafindan bastırılırsa blastosistlerin oluşumunda bazı eksikliklere neden olur. Ek olarak hücrelerin pluripotent kapasitesini uyaran Oct3/4 ekspresyonunu düzenler. Öte yandan Klf4 hücre bölünmesinden sorumludur ve ekspresyonun da herhangi bir soruna maruz kalırsa hücrelerin G1-S fazında kalmasını sağlar ${ }^{47}$. Bundan dolayı ' $G$ ' fazı kontrol noktalarında etkilidir. Aynı zamanda embriyonik kök hücrelerin kendi kendilerini yenileyebilme özellikleri için de gereklidir. Ayrıca Klf'nin p53'ü doğrudan bastırdığı ve p53 proteininin embriyonik kök hücre farklılaşmaları sırasında NANOG'u baskıladığı gösterilmiştir ${ }^{48}$. Bu nedenle Klf4, NANOG ve diğer embriyonik kök hücrelerine özgü genlerin p53 represyonuyla aktivasyona da katkıda bulunduğu söylenebilir. P53 geni vücutta bir tür tümör baskılayıcı gendir ve bu nedenle Klf-4 fonksiyonu tümör oluşumunda önemli rol oynar ${ }^{49}$. Son olarak c-Myc tümör oluşumuna neden olan bir proteindir. Özellikle farelerde teratoma oluşumunu uyarır. Genellikle Klf-4 ve c-Myc transkripsiyon faktörleri onkogen olarak bilinirler $^{50}$. Bu iki genin tümör oluşum eğilimi nedeniyle Yu ve ark. Yamanaka ve Takahashi’nin çalışmalarından bir yıl sonra Lin28 ve NANOG olan diğer iki önemli transkripsiyon faktörünü İPKH elde edilmesinde kullanılmasını önerdi ${ }^{40}$. Ayrıca c-Myc hücrelerin kromozomal yapısının düzenlenmesi için gereklidir. $\mathrm{Bu}$ kök hücre biyolojisinin hücrelerin pluripotent özelliğini anlayabilme de önemli olduğunu göstermektedir. Ayrica histon asetil-transferaz (HAT) kompleksleri ile birleşir ${ }^{51}$. Böylece Oct3/4 ve Sox2'nin kendi hedef lokasyonlarına bağlanmasına izin verir ${ }^{52,53}$. Önceden bilinen dört ana transkripsiyon faktörünün (Oct4, Sox2, Klf4 ve c-Myc) retroviral transfeksiyonu fare embriyonik fibroblastlarını (MEFC'ler) embriyonik kök hücre benzeri hücrelere dönüştürebilir. Bu indüklenmiş pluripotent hücreler üç germ katmanının hepsine farklılaşabilir ve fare embriyonik kök hücreleri gibi kimeralara katkıda bulunabilir. Yeniden prog- 
ramlama için transkripsiyon faktörlerinin transdüksiyonu ile ilgili endişeler bu mekanizmanın verimliliğinden kaynaklanmaktadır. Bu nedenle birçok grup G9a histon metiltransferaz, histon deasetilaz, MEK ve GSK3 sinyallenmesini inhibe eden transkripsiyon faktörlerini ve küçük kimyasal molekülleri birleştirerek IPXK'leri somatik hücrelerden türetme verimliliğini arttırmaya çalışmıştır. Bu çalışmalar temel transkripsiyonel ağın kromatin yeniden modellenmesi ve sinyal yolakları ile yakından ilişkili olduğunu göstermektedir ${ }^{54,55}$.

Retroviral vektörler moleküler biyoloji, genetik ve ayrıca klonlama çalışmalarında da yaygın olarak kullanılan yüksek verimlilikte çalışan viral vektörlerdir. Daha önceki çalışmalarda bir retroviral vektör olan Moloney Murin Lösemi virüsü (MMLV) ve transgenleri genellikle embriyonik kök hücrelerde susturulmuş olan 5' MMLV LTR paramotorları tarafindan tetiklenmiştir. Aslında yeniden programlama faktörleri IPKH'lerine yeniden programlandiktan sonra DNA metilasyonuyla susturulmuştur. Bununla birlikte, MMLV LTR paramotoru sıklıkla kendiliğinden tekrar aktif hale getirilmiş ve daha sonra İPKH kaynaklı kimerik farelerde tümör oluşumuna neden olan İKH'lerinin farklılaşması üzerine c-Myc ekspresyonunu tetiklemiştir ${ }^{56}$. Bu kimerik farelerde tümör oluşumuna neden olduğu anlamına gelmektedir ${ }^{57}$. Ayrıca viral genlerin rastgele yerleştirilmeleri konakçı genlerin aktivasyonu veya inaktivasyonu gibi temel genetik modifikasyona neden olabilmektedir. Dolayısı ile de bazı mutasyonlara ve tümör oluşumuna neden olabilmektedir $^{11}$. Bu nedenle bu sorunları çözmek için birçok çalışma yapılmıştır. Özellikle dışsal gen içermeyen İPH yetişkin fare hepatositlerinden ve fare embriyonik fibroblastlarından (MEF'ler) adeno viral transfeksiyon ve plazmid transfeksiyonu ile üretilebilmesi amaçlamıştır $^{58}$. Bu deneyler dört programlama faktörünün geçici ifadesinin somatik hücrelere pluripotent özelliği yeniden kazandırabilmek için önemlidir ${ }^{59}$. Tablo I'de görüldüğü gibi yeniden programlama prosedürünü yürütmek için çok çeşitli taşıyıcı vektörler bulunmaktadır. Somatik hücreler ayrıca Sendai virüsü ve tek polikistronik vektörler ile yeniden programlanmıştır. Ancak kromozoma entegre olmayan vektör sistemleri tarafindan yeniden programlama verimliliğ retroviral vektör sistemine göre çok daha düşüktür ${ }^{60,61}$.

Bu dezavantajı önlemek için birkaç grup entegrasyon bağımlı gen taşıyıcı vektörleri loxP bölgesi ile birleştirmiş ve daha sonra Cre rekombinazın geçici ekspresyonu ile konakçı genomdan çıkarılabilmiştir ${ }^{6}$. Tablo I'de indüklenmiş pluripotent hücrelerin yeniden programlanması için transdüksiyon stratejisine yönelik vektörler gösterilmiştir. Dışsal gen içermeyen İPKH üretmek için başka bir yaklaşım transpozitlerin ekspresyonu ile konakçı genomundan çıkarılabilecek mobil genetik materyal olan piggyBac transpozonlarını kullanmaktır ${ }^{62}$.
Tablo I. İ KH elde edilmesi için kullanılan vektör sistemleri ve verimlilikleri

\begin{tabular}{|c|c|c|c|}
\hline Tür & Vektör Sistemi & Verimlilik & Yil \\
\hline Fare & Retrovirus & $10^{-4}$ & 2006 \\
\hline \multicolumn{4}{|c|}{$\begin{array}{l}\text { Entegre olmamıs } \\
\text { vektör }\end{array}$} \\
\hline Fare & Adenovirüs & $10^{-5}-10^{-5}$ & 2008 \\
\hline Insan & Adenovirüs & $2 \times 10^{-6}$ & 2009 \\
\hline Insan & Sendai Virüs & $10^{-3}-10^{-2}$ & 2009 \\
\hline Fare & Plasmid & $10^{-6}-2 \times 10^{-3}$ & 2008 \\
\hline Insan & Episomal Vektör & $10^{-6}-2 \times 10^{-3}$ & 2009 \\
\hline Insan & Episomal Plasmid Vektō̃ & $1 \times 10^{-5}-3 \times 10^{-4}$ & 2011 \\
\hline Insan & Mini dairesel vektör & $5 \times 10^{-3}$ & 2010 \\
\hline Fare & $\begin{array}{l}\text { Liposomal } \\
\text { magnetofesyon }\end{array}$ & $4 \times 10^{-4}$ & 2012 \\
\hline \multicolumn{4}{|c|}{$\begin{array}{l}\text { Entegrasyon sonrası } \\
\text { delesyon }\end{array}$} \\
\hline Insan & $\begin{array}{l}\text { Retroviral transfesyon+ } \\
\text { Cre } \\
\text { Vektôr }\end{array}$ & - & 2012 \\
\hline Fare/Insan & Piggy Back Transposon & $3 \times 10^{-4}$ & 2009 \\
\hline Fare/Insan & Piggy Back Transposon & $\cdot$ & 2009 \\
\hline \multicolumn{4}{|c|}{$\begin{array}{l}\text { DNA'szz Vektồ } \\
\text { Sistemi }\end{array}$} \\
\hline Fare & $\begin{array}{l}\text { Füzyon Protein } \\
\text { Trandüksüyonu }\end{array}$ & $6 \times 10^{-3}$ & 2009 \\
\hline Insan & $\begin{array}{l}\text { Füzyon Protein } \\
\text { Trandüksüyonu }\end{array}$ & $10^{-3}$ & 209 \\
\hline Fare/Insan & mRNA Transüksüyonu & $1 \times 10^{-2}$ & 210 \\
\hline \multicolumn{4}{|c|}{ Kimyasal Indūksiyon } \\
\hline Fare & $\begin{array}{l}\text { Küçülk Molekül } \\
\text { Bileșenleri }\end{array}$ & $2 \times 10^{-3}$ & 2013 \\
\hline
\end{tabular}

2009'da iki grup DNA'sız (protein temelli) İPKH'lerin Shen Ding ve Kim'in yöntemleri olan rekombinant proteinler kullanılarak dört yeniden programlama faktörü ile fare ve insan fibroblastlarından elde edilebildiğini göstermiştir ${ }^{63}$. Başka bir yaklaşım ise proteinlerin somatik hücrelerden transdüksiyonunda nükleik asit kullanmadan yeniden programlama faktörlerini kodlayan sentetik mRNA'ların somatik hücrelere aktarılması ile İPKH üretilmesinin daha verimli ve güvenli bir yol olması üzerine Rossi Grubu tarafindan çalış1lmıştır ${ }^{64}$. Sentetik mRNA'lar insandaki interferon aracılı doğal bağışıklık tepkisi nedeniyle sitotoksisiteye neden olabilir. Dışsal gen tek iplikli RNA'nın (ssRNA) memeli hücrelerinde interferon ve NF-kB'ye bağlı yolaklar yoluyla antiviral savunmayı aktive ettiği bilinmektedir. Aynı zamanda bu sentetik mRNA düşük translasyon etkinliği ve verilen mRNA'nın kararsızlığı gibi bazı negatif etkilere neden olabilmektedir ${ }^{65}$. Bunlara ek olarak son zamanlarda yapılan çalışmalar ile viral olmayan vektör sistemleri kullanılarak da İPKH eldesinin mümkün olduğu gösterilmiştir. Varlı ve ark. lipit bazlı bir nano-taşıyıcı sistemi dizayn ederek ilk kez fare fibroblast hücrelerini yeniden programlanması amacı ile kullanmışlardır ${ }^{66}$.

\section{Indüklenmiş Pluripotent Kök Hücre Karakterizasyonu}

Tanımlama prosedürü ayrıca karakterizasyon olarak da adlandırılabilir ve aslında İ KH'lerin pluripotent özelliğe sahip olan embriyonik kök hücreler ile benzerliğini göstermek amaçlanmaktadır. İlk belirleme yöntemi olarak elde edilen hücreler mikroskopla incelenmesidir. Embriyonik kök hücreler uzun süreli büyüme ve kendini yenileme özelliklerine sahip olmal1dır. Bu nedenle bilim adamları hücrenin sağlıklı göründüğünü ve farklılaşmadığını görmek için kültürleri mikroskopla inceler. İndüklenmiş pluripotent hücrelerin morfolojisi mikroskop altındaki embriyonik kök hücrelerle benzerdir ${ }^{11}$. 
Mikroskop görüntülerinin incelenmesinin yanında bilim insanları genellikle NANOG, Sox2, Klf4, c-Myc, LIN28 ve Oct3/4 olan farklılaşmamış hücrelerinin sahip olduğu transkripsiyon faktörlerinin varlığını araştırabilmektedir $^{67}$. Bu yöntemde yeniden programlama ile değiştirilen hücrelerin PCR sonuçları karşılaştırılabilir $^{68}$. Diğer taraftan da farklılaşmamış hücrelerin hücre yüzey belirteçleri incelenebilmektedir. Ayr1ca SCID farelerine cilt altı implantasyon uygulaması ile teratom oluşumu da takip edilmektedir. Mikroskop altında kromozom incelemesi $G$ fazının tanımlanması için başka bir seçenek de olabilir ${ }^{69}$. Hücreler metafaz anında durdurulur ve 1şık mikroskobu altında incelendikten sonra Giemsa ile boyanır. Böylece karyotip incelenmesi yapılabilmektedir. Ayrıca DNA parmak izi olan ve DNA metilasyonunun analizi olan indüklenmiş pluripotent hücreler için genomik karakterizasyonlar da kullanılabilmektedir. Son olarak pluripotent kapasitesi incelenebilir ${ }^{70}$. Bu yolla kültürlerde hücrelerin kendiliğinden farklılaşması incelemek, hücrelerin üç germ tabakasını elde etmesini incelemek ve enjeksiyon prosedürü ile fare teratoma tümör oluşumunun incelenmesi gibi özellikler İPKH'lerin karekterizasyonu için kullanılan en temel metotlardır. Bu metotların birkaç tanesinin bir arada kullanımı elde edilen hücrelerin kimlik tespiti için kullanılabilir.

Pluripotent kök hücreleri elde ettiğimizi bu yöntemler ile onayladıktan sonra bu hücreler birçok farklı özelleşmiş hücre tipini elde etmek amacı ile kullanılabilmektedirler. Şekil 6 bize kısa bir özet niteliği taşımaktadir.

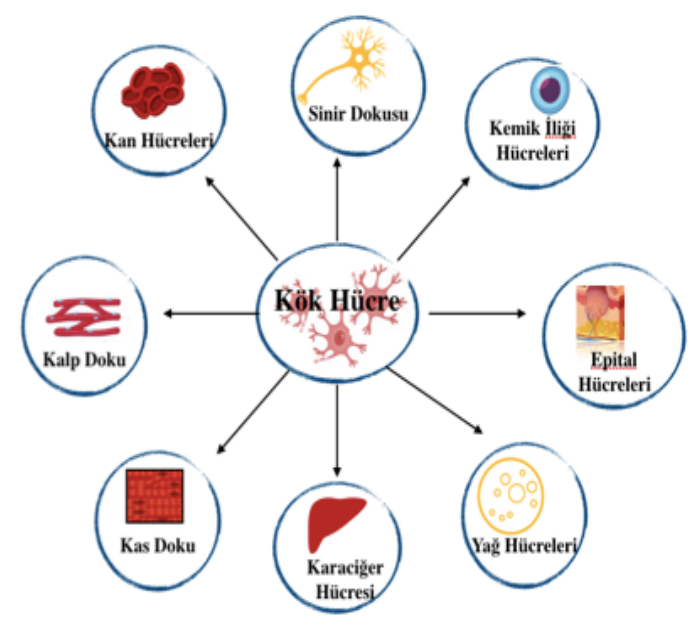

Şekil 6.

Kök hücrelerden türetilen somatik hücre çeşitleri

Indüklenmiş Pluripotent Kök Hücrelerin Rejenaratif Tiptaki Yeri

Bilindiği üzere İPKH'ler insan kan, keratinosit ve dermal fibroblast hücrelerinden yüksek verimlilikte elde edilebilmektedir ${ }^{71,72,73}$. Ayrica IPKH'lerin elde edilmesi ile embriyonik kök hücreler ile ilgili yaşanan kaynak sıkıntısı ve etik sorunların da önüne geçilmesi amaçlanmaktadır. Bu kolay erişim özelliklerinden dolayı İPKH'ler özellikle hastalık modelleme, ilaç taramaları için kullanılmakta ve ayrıca gelecekte klinik tedavide otolog hücre naklinin en önemli potansiyeli olarak görülmektedir. Çoğu durumda İPKH'lerin hastalıkla ilgili hücre tipine in vitro farklılaşması bildirilmiştir ve literatürde hastaya özgü İPKH'lerin belirli hastalık özellikleri sergilediğini öne süren birçok çalışma bulunmuştur. Örneğin spinal müsküler atrofi (SMA) hastalarından türetilen İPKH'lerin in vitro farklılaşması bu hastalık sırasında görülen motor nöronların gelişimsel kaybını yansıtabilen progresif motor nöron kaybını göstermiştir. Sergilenmekte olan bu in vitro çalışmalar ile İPKH teknolojisini kullanarak hastalık modellemesinin gerçekte uygulanabilir olabileceğine dair kanıtlar elde edilmiştir ${ }^{74}$. Bazı eksikliklerin neden olduğu çeşitli hastalık türleri IPKH'ler kullanılarak incelenmiştir. Park ve arkadaşları hastalık modelleri ve ilaç keşfi çalışmaları için Adenozin deaminaz eksikliğine bağlı şiddetli immün yetmezlik (ADA-SCID), Shwachman-Bodian-Diamond sendromu (SBDS), Gaucher hastalığı (GD) tip III gibi çeşitli hastalıkları kaynağını insan vücudu olan İPKH'ler kullanarak anlamaya çalışmışlardır. Çalışmalarını dermal fibroblastlar veya kemik iliğinden türetilmiş mezenkimal kök hücreleri kullanarak ve dört veya üç (c-Myc transkripsiyon faktörü hariç) trankripsiyon faktörünün transdüksiyonu yoluyla insan İPKH'lerinin üretimi için kullanmışlardır. Çalışmalarından ADA-SCID, SBDS ve Gaucher hastalığı tip III'ün otozomal resesif olan konjenital bozukluklar gibi klasik bir Mendel Kalıtım tarzında kalıtsal olduğu göstermişlerdir. Yapılan çalışmada hastalıkların normal hematopoez ve immünolojik fonksiyon için hayati öneme sahip genlerdeki nokta mutasyonlardan kaynaklandığ1 gösterilmiştir ${ }^{75,76}$. Başka bir açıdan terapötik rejenerasyon için İPKH'lerin transplantasyonu ile ilgili olarak şimdiye kadar ki en ilgi çekici çalışma IPKH'lerden türetilen hematopoietik hücrelerin orak hücreli aneminin insanlaştırılmış fare modelinde kan hücresi fenotipini azaltabilmesi olmuştur. Çalışma da İPKH'ler insan hemoglobin sekansında bir mutasyon taşıyan transgenik bir fareden türetilmiştir ve ardından homolog rekombinasyon yoluyla genetik olarak düzeltilmiştir. Düzeltilmiş İPKH'lerin hematopoietik progenitörlere in vitro farklılaşması ve ardından orijinal transgenik farelere transplantasyonu normal hemoglobin seviyelerinin restorasyonunu gelişmiş bir fenotip ile sonuçlanmıştır ${ }^{77}$. Diğer organlar için de benzer nakil temelli yaklaşımlar bildirilmiştir. Örneğin fare İPKH'lerinden türetilen kısmen saflaştırılmış dopaminerjik nöronlar Parkinson hastalığının sıçan modelinde klinik semptomlarını iyileştirmeyi başarmıştır ${ }^{78}$. Benzer şekilde insan IPKH'lerinden türetilmiş hücrelerin deneysel olarak yaralanan kemirgen kalbine transplantasyonu sonucun da kardiyak kasılma fonksiyonunda bir dereceye kadar kısa vadeli fonksiyonel iyileşme göstermiştir $^{79}$. Moad ve arkadaşları ise insan prostat 
ve idrar yolu hücrelerini İPKH eldesi için ve ayrıca bu hücrelerinin farklılaşmalarını düzenleyen mekanizmaları incelemek için kullanmışlardır. Çalışmalarda kullanılan hücreler farklı yaş aralıkların da bulunan erkek ve kadın hastalardan alınan biyopsi örneklerinden sağlanmıştır. Çalışmalarıyla mesane, prostat ve üreter stromal fibroblastlarının, pluripotent özellik kazandırmak üzere yeniden programlanması amaçlanmıştır. Daha sonra transdüksiyona tabi tutulan stromal hücrelerin homojenliği hücre belirteçleri kullanılarak gerçek zamanlı ters transkripsiyon-polimeraz zincir reaksiyonu (RT-PCR) ile doğrulanmıştır. Doğrulama; CD24 epiteli, CD45 hematopoietiği, von Willebrand faktör endoteli, CD146 endotelyalyası, a-düz kas aktin [SMA] stromal düz kası ve Thy-1 hücre yüzey antijeni [CD90] gibi belirteçler kullanılarak saptanmıştır. Prostat kaynaklı İPKH'lerden prostat dokusunun başarılı bir şekilde oluştuğu gözlemlenmiştir. Mesane ve üreter kaynaklı IPKH'ler de karakteristik EKH morfolojisi, ilgili belirteçlerin ekspresyonu ve üç germtabakasının da üretilmesi gözlemlenerek pluripotent özelliklerin kazandırıldığı böylece tespit edilmiştir. Geleneksel cilt hücrelerinden türetilen İPKH'lerin aksine, prostat kaynaklı İPKH'ler, androjen reseptörü ve prostata özgü antijen indüksiyonu ile karakterize edilen prostat epiteline özgü farklılaşma oluşturma konusunda başarılı sonuçlar göstermiştir. Benzer sonuçlar üreter kaynaklı IPKH'ler için de belirtilmiştir. Ürotelyal spesifik belirteçlerin ekspresyonunda da gösterildiği gibi mesane farklılaşması ciltten türetilen İPKH'ler ile karşılaştırıldığında daha etkili olduğu gösterilmiştir. Aslında yapılan çalışmalar ile aynı zamanda deri fibroblastlarından türetilen İPKH'lere kıyasla; insan prostatı ve idrar yolu dokusu kendi ana organ soylarına geri farklılaştırılabilen İPKH'leri oluşturmak için kullanılabileceği anlaşılmıştır. Özellikle de prostat kaynaklı İKH'ler ve üreter kaynaklı IPKH'lerin nesli normal ve hastalıklı prostat ve mesane biyolojisi çalışmaları için önemli bir potansiyel sunabileceği ve uygun bir erişime hazır model sağlayabileceğini göstermiştir. ${ }^{76}$ Kazuki ve arkadaşları ise bir insan Duchhene Musküler Distrofi (DMD) hastasından alınan İPKH'lerdeki genetik eksikliği düzeltmeye odaklanmışlardı. Tam Distrofin (DYS) dizisinin ifadesi için İnsan Yapay Kromozomu (IYYK) kulland1lar. Bunu İPKH'lerin oluşturulması için DMD hastasından alınan fibroblastları kullanıldı. IYK, Mikrohücre aracılı kromozom transferi (MMCT) kullanılmasiyla DYS-IYYK (İYK'de tam genomik distrofin dizisi) aktarımı ile İPKH'lerde bulunan Distrofin genindeki silinme veya mutasyonun düzeltilmesi için kullanılmıştır $^{80}$. IPKH'ler ayrıca hepatositlerin işlev kaybının neden olduğu rahatsızlar için hepatosit eldesi amacı ile kullanılabilir. İPKH'ler çeşitli karaciğer problemleri için hepatosit üretimi için umut vaad edicidir. İPKH'ler aynı zamanda farklı dokuların onarımı için çeşitli hücrelerin üretimi için de kullanılabilir. Örneğin kalp kapakçıkları, damarlar ve iskemik dokuların onarımı için kardiyovasküler hücrelerin elde edilmesi amacıyla kullanılabilir. Ancak bu uygulamalar da tedavi sonrası olumsuz etkiler ya da büyük miktarlarda saf ve kaliteli hücreler oluşturmak için protokollerin standardizasyonu gibi sınırlamalar karşımıza çıkmaktadır. Bu engeller bir kez aşıldıktan sonra İPKH'lerin kardiyovasküler hücreleri oluşturmak ve ilgili hastalıkların incelenmesi için uygun zemin hazırlanacağı düşünülmektedir ${ }^{81}$. Başka bir açıdan İPKH'ler birçok hücre ölümünden kaynaklanan çeşitli dejeneratif hastalıkların gen terapisi ile tedavisini de mümkün kılmıştır. Özellikle de gözün retina dejenerasyonunun görme bozukluğuna neden olduğu bilinen Retinitis pigmentosa (RP) hastalığının tedavisin de İPKH'lerin kullanılması karşımıza çıkmaktadır. İnsan kaynaklı fibroblast hücrelerin, lentiviral vektör transdüksiyonu yardımıyla İPKH eldesi için kullanılmıştır. Bunların çubuk foto reseptör hücrelerine farklılaştığı gösterilmiştir. Yapılan çalışma ile retina pigmentli epitelden farklılaşmasının Retinal Pigmentoza ve Yaşa Bağlı Makula Dejenerasyonu (AMD) hastaları tedavisi için faydalı olduğu gösterilmiştir ${ }^{82}$. Kısaca hücresel pluripotent özelliklerin ve yeniden programlamanın moleküler mekanizmalarının anlaşılmasında birtakım ilerlemeler kaydedilmesi gerekmesine rağmen IPKH teknolojisi kullanılarak yeni tedavi yaklaşımlarının ve ilaçların keşfedilebilmesi olasılığı, hastalık modellerinin oluşturulması ve temel/klinik çalışmaların hız kazanması sağlanmaktadır.

\section{Sonuç}

Sonuç olarak günümüzde kök hücre çalışmaları embriyonik kök hücrelerinin eldesinin zor ve meşakkatli oluşu aynı zamanda etik konulardan kaynaklanan sorunlardan dolayı yönünü İPKH'lerin elde edilmesine çevirmiştir. İndüklenmiş pluripotent kök hücreler hücresel tedaviler ve kişiye özel tedaviler için iyi bir kaynak olarak popülerliğini korumaktadır. Bu hücrelerin eldesi için birçok farklı yöntem denenmiş ve denenmeye de devam etmektedir. Ayrıca çeşitli genetik hastalık modeline sahip hücrelerden indüklenmiş pluripotent hücrelerin eldesi ve fonksiyonel verimliliklerinin artırılması başlıca çalışmalar arasında yerini almıştır. Bu konu ile ilgili çalışmaların hız kesmeden devam edeceği ve bilim insanlarının azminin bizlere umut olacağı aşikardır.

\section{Kaynaklar}

1. El-Badri N, Ghoneim MA. Mesenchymal stem cell therapy in diabetes mellitus: Progress and challenges. J Nucleic Acids. 2013. doi:10.1155/2013/194858

2. Pileggi A. Mesenchymal stem cells for the treatment of diabetes. Diabetes. 2012. doi:10.2337/db12-0355

3. Deshmukh RS, Kovács KA, Dinnyés A. Drug discovery models and toxicity testing using embryonic and induced pluripotent 


\section{İndüklenmiş Pluripotent Kök Hücreleri}

stem-cell-derived cardiac and neuronal cells. Stem Cells Int 2012. doi:10.1155/2012/379569

4. Spitalieri P, Talarico VR, Murdocca M, Novelli G, Sangiuolo F. Human induced pluripotent stem cells for monogenic disease modelling and therapy. World J Stem Cells. 2016. doi:10.4252/wjsc.v8.i4.118

5. Amabile G, Meissner A. Induced pluripotent stem cells: current progress and potential for regenerative medicine. Trends $\mathrm{Mol}$ Med. 2009. doi:10.1016/j.molmed.2008.12.003

6. Soldner F, Hockemeyer D, Beard C, et al. Parkinson's Disease Patient-Derived Induced Pluripotent Stem Cells Free of Viral Reprogramming Factors. Cell. 2009. doi:10.1016/j.cell.2009.02.013

7. Bunge MB. Novel combination strategies to repair the injured mammalian spinal cord. J Spinal Cord Med. 2008 doi:10.1080/10790268.2008.11760720

8. Thomson JA. Embryonic stem cell lines derived from human blastocysts. Science (80- ). 1998;282(5391):1145-1147. doi:10.1126/science.282.5391.1145

9. Cheung TH, Rando TA. Molecular regulation of stem cell quiescence. Nat Rev Mol Cell Biol. 2013. doi:10.1038/nrm3591

10. Kim JS, Choi HW, Choi S, Do JT. Reprogrammed pluripotent stem cells from somatic cells. Int J Stem Cells. 2011;4(1):1-8. doi:10.15283/ijsc.2011.4.1.1

11. Avcılar H, Saraymen B, Özturan OÖ, Köker MY. Embriyonik Kök Hücreler ve İndüklenmiş Pluripotent Kök Hücreler. Asthma Allergy Immunol. 2017. doi:10.21911/aai.22

12. Ateş U. Kök hücreyi tanıyalım. FNG Bilim Tıp Transplant Derg. 2016. doi:10.5606/fng.transplantasyon.2016.004

13. Kansu Emin. Kök hücre biyolojisi ve plastisitesinde günce kavramlar. Hacettepe Med J. 2005.

14. Martin-Rendon E, Watt SM. Exploitation of stem cell plasticity. Transfus Med. 2003. doi:10.1111/j.1365-3148.2003.00462.x

15. Santoro A, Vlachou T, Carminati M, Pelicci PG, Mapelli M. Molecular mechanisms of asymmetric divisions in mammary stem cells. EMBO Rep. 2016. doi:10.15252/embr.201643021

16. Kıvanç M, Öztürk Ş, Gökalp S, Özdemir İ, Tuğlu İ. Adipoz Kaynaklı Kök Hücreler ve Uygulama Alanları. Cukurova Med J. 2015. doi:10.17826/cutf.44976

17. Erdal Y, Seçkin UD. Klinik çalışmalar açısından güncel mezenkimal kök hücre uygulamaları. İstanbul Bilim Üniversitesi Florence Nightingale Transplant Derg. 2017.

18. Takahashi K, Yamanaka S. Induction of Pluripotent Stem Cells from Mouse Embryonic and Adult Fibroblast Cultures by Defined Factors. Cell. 2006. doi:10.1016/j.cell.2006.07.024

19. Doss MX, Koehler CI, Gissel C, Hescheler J, Sachinidis A. Embryonic stem cells: A promising tool for cell replacement therapy. J Cell Mol Med. 2004. doi:10.1111/j.15824934.2004.tb00471.x

20. Keller G. Embryonic stem cell differentiation: Emergence of a new era in biology and medicine. Genes Dev. 2005. doi:10.1101/gad.1303605

21. Gardner RL, Brook FA. Reflections on the biology of embryonic stem (ES) cells. Int J Dev Biol. 1997;41(2):235-243. doi:10.1387/ijdb.9184330

22. Evans MJ, Kaufman MH. Establishment in culture of pluripotential cells from mouse embryos. Nature. 1981. doi:10.1038/292154a0

23. Shen H, Zhang L, Liu M, Zhang Z. Biomedical applications of graphene. doi:10.7150/thno.3642

24. Nichols J, Evans EP, Smith AG. Establishment of germ-linecompetent embryonic stem (ES) cells using Differentiation Inhibiting Activity. Development. 1990

25. Dahéron L, Opitz SL, Zaehres H, et al. LIF/STAT3 signaling fails to maintain self-renewal of human embryonic stem cells.
Stem Cells. 2004;22(5):770-778

26. Xiao L, Yuan X, Sharkis SJ. Activin A Maintains Self-Renewal and Regulates Fibroblast Growth Factor, Wnt, and Bone Morphogenic Protein Pathways in Human Embryonic Stem Cells. Stem Cells. 2006. doi:10.1634/stemcells.2005-0299

27. Thomson JA, Itskovitz-eldor J, Shapiro SS, et al. Derivation of pluripotent epiblast stem cells from mammalian embryos. Nature. 2013. doi:10.1101/gad.1811609

28. Canals I, Ginisty A, Quist E, et al. Rapid and efficient induction of functional astrocytes from human pluripotent stem cells. Nat Methods. 2018. doi:10.1038/s41592-018-0103-2

29. Patapoutian A, Wold BJ, Wagner RA. Evidence for developmentally programmed transdifferentiation in mouse esophageal muscle. Science (80- ). 1995. doi:10.1126/science.270.5243.1818

30. González F, Boué S, Belmonte JCI. Methods for making induced pluripotent stem cells: Reprogramming à la carte. Nat Rev Genet. 2011. doi:10.1038/nrg2937

31. Can A. A concise review on the classification and nomenclature of stem cells. Turkish J Hematol. 2008.

32. Pralong D, Mrozik K, Occhiodoro F, et al. A novel method for somatic cell nuclear transfer to mouse embryonic stem cells. Cloning Stem Cells. 2005;7(4):265-271.

33. Fulka J, Loi P, Fulka H, Ptak G, Nagai T. Nucleus transfer in mammals: Noninvasive approaches for the preparation of cytoplasts. Trends 2004. doi:10.1016/j.tibtech.2004.04.002

34. Briggs R, King TJ. Transplantation of living nuclei from blastula cells into enucleated frogs' eggs. Proc Natl Acad Sci. 1952. doi:10.1073/pnas.38.5.455

35. Wernig $M$, Meissner $A$, Foreman $R$, et al. In vitro reprogramming of fibroblasts into a pluripotent ES-cell-like state. Nature. 2007. doi:10.1038/nature05944

36. Seyalioğlu İ, Şenel Eraslan B, Hot İ, Demircan YT, Çetin G. Klonlamaya Genetik, Etik ve Hukuksal Açıdan Yaklaşım. Adli Tip Derg. 2007

37. Tada S, Tada T, Lefebvre L, Barton SC, Surani MA. Embryonic germ cells induce epigenetic reprogramming of somatic nucleus in hybrid cells. EMBO J. 1997. doi:10.1093/emboj/16.21.6510

38. Bhutani N, Brady JJ, Damian M, Sacco A, Corbel SY, Blau HM. Reprogramming towards pluripotency requires AIDdependent DNA demethylation. Nature. 2010. doi:10.1038/nature08752

39. Takahashi K, Tanabe $\mathrm{K}$, Ohnuki $\mathrm{M}$, et al. Induction of Pluripotent Stem Cells from Adult Human Fibroblasts by Defined Factors. Cell. 2007. doi:10.1016/j.cell.2007.11.019

40. Yu J, Vodyanik MA, Smuga-Otto K, et al. Induced pluripotent stem cell lines derived from human somatic cells. Science (80- ). 2007. doi:10.1126/science. 1151526

41. Schöler HR, Ruppert S, Suzuki N, Chowdhury K, Gruss P. New type of POU domain in germ line-specific protein Oct-4. Nature. 1990. doi:10.1038/344435a0

42. Okamoto K, Okazawa H, Okuda A, Sakai M, Muramatsu M, Hamada H. A novel octamer binding transcription factor is differentially expressed in mouse embryonic cells. Cell. 1990. doi:10.1016/0092-8674(90)90597-8

43. Abed M, Kenyagin-Karsenti D, Boico O, Orian A. DamID: A methylation-based chromatin profiling approach. Methods $\mathrm{Mol}$ Biol. 2009. doi:10.1007/978-1-60327-414-2_11

44. Saigal S, Bhargava A. Stem cell - is there any role in tumorigenic activity. Turk Patoloji Dergisi/Turkish J Pathol. 2011. doi:10.5146/tjpath.2011.01055

45. Boyer LA, Tong IL, Cole MF, et al. Core transcriptional regulatory circuitry in human embryonic stem cells. Cell. 2005. doi:10.1016/j.cell.2005.08.020 


\section{N.T. Laçin ve N.P. Cesur}

46. Loh YH, Wu Q, Chew JL, et al. The Oct4 and Nanog transcription network regulates pluripotency in mouse embryonic stem cells. Nat Genet. 2006. doi:10.1038/ng1760

47. Zhao W, Hisamuddin IM, Nandan MO, Babbin BA, Lamb NE, Yang VW. Identification of Krüppel-like factor 4 as a potential tumor suppressor gene in colorectal cancer. Oncogene. 2004. doi:10.1038/sj.onc.1207067

48. Rowland BD, Bernards R, Peeper DS. The KLF4 tumour suppressor is a transcriptional repressor of p53 that acts as a context-dependent oncogene. Nat Cell Biol. 2005. doi:10.1038/ncb1314

49. Li Y, McClintick J, Zhong L, Edenberg HJ, Yoder MC, Chan RJ. Murine embryonic stem cell differentiation is promoted by SOCS-3 and inhibited by the zinc finger transcription factor Klf4. Blood. 2005. doi:10.1182/blood-2004-07-2681

50. Sevim H, Gürpinar ÖA. İndüklenmiş Pluripotent Kök Hücreler Ve Uygulamalari\{Dotless\}. Marmara Med J. 2012. doi:10.5472/MMJ.2011.01922.1

51. McMahon SB, Wood MA, Cole MD. The Essential Cofactor TRRAP Recruits the Histone Acetyltransferase hGCN5 to cMyc. Mol Cell Biol. 2000. doi:10.1128/mcb.20.2.556-562.2000

52. Adhikary S, Eilers M. Transcriptional regulation and transformation by Myc proteins. Nat Rev Mol Cell Biol. 2005. doi:10.1038/nrm1703

53. Fernandez PC, Frank SR, Wang L, et al. Genomic targets of the human c-Myc protein. Genes Dev. 2003. doi:10.1101/gad.1067003

54. Huangfu D, Maehr R, Guo W, et al. Induction of pluripotent stem cells by defined factors is greatly improved by smallmolecule compounds. Nat Biotechnol. 2008 doi:10.1038/nbt1418

55. Silva J, Barrandon O, Nichols J, Kawaguchi J, Theunissen TW, Smith A. Promotion of reprogramming to ground state pluripotency by signal inhibition. PLoS Biol. 2008. doi:10.1371/journal.pbio.0060253

56. Bayart E, Cohen-Haguenauer O. Technological Overview of iPS Induction from Human Adult Somatic Cells. Curr Gene Ther. 2013. doi:10.2174/1566523211313020002

57. Verfaillie C. The undoing of differentiation by four defined factors: A big step forward towards generating patient specific pluripotent stem cells. J Hepatol. 2008. doi:10.1016/j.jhep.2008.08.007

58. Abad M, Mosteiro L, Pantoja C, et al. Human and Mouse Induced Pluripotent Stem Cells Are Differentially Reprogrammed in Response to Kinase Inhibitors. Stem Cell Reports. 2015. doi:10.1002/stem.2071

59. Chatterjee S, Chaklader M, Basak P, et al. An animal model of chronic aplastic bone marrow failure following pesticide exposure in mice. Int $J$ Stem Cells. 2010 doi:10.15283/ijsc.2010.3.1.54

60. Egashira T, Seki T, Yuasa S, et al. Generation of induced pluripotent stem cells in healthy volunteers and patients with hereditary heart disease. J Mol Cell Cardiol. 2010. doi:10.1016/j.yjmcc.2010.03.009

61. Ramos-Mejia V, Mũoz-Lopez M, Garcia-Perez JL, Menendez P. IPSC lines that do not silence the expression of the ectopic reprogramming factors may display enhanced propensity to genomic instability. Cell Res. 2010. doi:10.1038/cr.2010.125

62. Plews JR, Li JL, Jones M, et al. Activation of pluripotency genes in human fibroblast cells by a novel mRNA based approach. PLoS One. 2010. doi:10.1371/journal.pone.0014397

63. Zhou H, Wu S, Joo JY, et al. Generation of Induced Pluripotent Stem Cells Using Recombinant Proteins. Cell Stem Cell.
2009;4(5):381-384. doi:10.1016/j.stem.2009.04.005

64. Warren L, Manos PD, Ahfeldt T, et al. Highly efficient reprogramming to pluripotency and directed differentiation of human cells with synthetic modified mRNA. Cell Stem Cell. 2010. doi:10.1016/j.stem.2010.08.012

65. Kim JS, Choi HW, Choi S, Do JT. Reprogrammed pluripotent stem cells from somatic cells. Int J stem cells. 2011;4(1):1.

66. Varli HS, Alkan F, Demirbilek M, Türkoğlu N. A virus-free vector for the transfection of somatic cells to obtain IPSC. $J$ Nanoparticle Res. 2019;21(11). doi:10.1007/s11051-019-46681

67. Maherali N, Sridharan R, Xie W, et al. Directly Reprogrammed Fibroblasts Show Global Epigenetic Remodeling and Widespread Tissue Contribution. Cell Stem Cell. 2007. doi:10.1016/j.stem.2007.05.014

68. Keller GM. In vitro differentiation of embryonic stem cells. Curr Opin Cell Biol. 1995. doi:10.1016/0955-0674(95)80071-9

69. Stojkovic M. Derivation of Human Embryonic Stem Cells from Day-8 Blastocysts Recovered after Three-Step In Vitro Culture. Stem Cells. 2004. doi:10.1634/stemcells.22-5-790

70. Gokhale PJ, Andrews PW. Characterization of human pluripotent stem cells. 2013.

71. Haase A, Olmer R, Schwanke K, et al. Generation of Induced Pluripotent Stem Cells from Human Cord Blood. Cell Stem Cell. 2009. doi:10.1016/j.stem.2009.08.021

72. Lowry WE, Richter L, Yachechko R, et al. Generation of human induced pluripotent stem cells from dermal fibroblasts. Proc Natl Acad Sci U S A. 2008. doi:10.1073/pnas.0711983105

73. Aasen T, Raya A, Barrero MJ, et al. Efficient and rapid generation of induced pluripotent stem cells from human keratinocytes. Nat Biotechnol. 2008. doi:10.1038/nbt.1503

74. Ebert AD, Yu J, Rose FF, et al. Induced pluripotent stem cells from a spinal muscular atrophy patient. Nature. 2009. doi:10.1038/nature07677

75. Park IH, Arora N, Huo H, et al. Disease-Specific Induced $\begin{array}{llll}\text { Pluripotent } & \text { Stem } & \text { Cells. } & \text { Cell. }\end{array}$ doi:10.1016/j.cell.2008.07.041

76. Singh VK, Kalsan M, Kumar N, et al. Induced pluripotent stem cells : applications in regenerative medicine, disease modeling , and drug discovery. 2015;3(February):1-18. doi:10.3389/fcell.2015.00002

77. Hanna J, Wernig M, Markoulaki S, et al. Treatment of sickle cell anemia mouse model with iPS cells generated from autologous skin. Science (80- ). 2007. doi:10.1126/science.1152092

78. Wernig M, Zhao JP, Pruszak J, et al. Neurons derived from reprogrammed fibroblasts functionally integrate into the fetal brain and improve symptoms of rats with Parkinson's disease. Proc Natl Acad Sci U S A. 2008. doi:10.1073/pnas.0801677105

79. Zhang J, Wilson GF, Soerens AG, et al. Functional cardiomyocytes derived from human induced pluripotent stem cells. Circ Res. 2009. doi:10.1161/CIRCRESAHA.108.192237

80. Kazuki Y, Hiratsuka M, Takiguchi M, et al. Complete genetic correction of iPS cells from duchenne muscular dystrophy. Mol Ther. 2010. doi:10.1038/mt.2009.274

81. Mahla RS. Stem cells applications in regenerative medicine and disease therapeutics. Int J Cell Biol. 2016. doi:10.1155/2016/6940283

82. Li Y, Tsai YT, Hsu CW, et al. Long-term safety and efficacy of human-induced pluripotent stem cell (iPS) grafts in a preclinical model of retinitis pigmentosa. Mol Med. 2012;18(9):1312-1319. doi:10.2119/molmed.2012.00242 